\title{
Experimental Investigation of Solar Desalination System Using Evacuated Tube Collector
}

\author{
Shridhar Kedar ${ }^{1,2^{*}}$, Arul Raj Kumaravel ${ }^{1}$, Anand K. Bewoor ${ }^{2}$ \\ ${ }^{1}$ Department of Mechanical Engineering, Koneru Lakshmaiah Education Foundation Green Field Vaddeswaram, Guntur \\ 522502, India \\ ${ }^{2}$ Department of Mechanical Engineering, MKSSS's Cummins College of Engineering for Women, Pune 411028, India
}

Corresponding Author Email: shridhar.kedar@cumminscollege.in

https://doi.org/10.18280/ijht.370220

Received: 23 July 2018

Accepted: 15 May 2019

\section{Keywords:}

solar desalination, evacuated tube collector, surface condenser, distilled water

\begin{abstract}
An experimental investigation is carried out for softening of hard water by using solar desalination system with an evacuated tube collector. The experimental study mainly involves various parameters such as the temperature of hard and soft water, an ambient temperature of water, water flow rate, intensity of solar radiation and wind velocity. The primary purpose for an experimental study to get a maximum amount of soft water using evacuated tube collector. It is observed that in evacuated tube solar collector system gives the higher outlet temperature of water and has the better results for the thermal performance of the energy system. The entire test is done for environmental and climatic conditions of Pune city which is located in the western region in India. The experimental analysis show that evacuated tube solar collector system gives 27-28 liters of soft water per day.
\end{abstract}

\section{INTRODUCTION}

Soft water is very essential for life, without soft water human as well as an animal cannot survive into nature. In the world, about $97 \%$ of the earth's water is salt water into the ocean and $3 \%$ fresh water contained in the groundwater, lakes, and rivers. Many researchers have studied the solar desalination system which mainly classified into membrane method, distillation method, RO, MED, MSF those methods need to consume fossils fuel and electric power. Section I discussed published literature till date reports with use of ETC to desalination system. Section II Literature review Section III discuss in detailed experimental results and results, and discussion is made in section IV conclusion and future scope is made in section V. In this set-up, solar energy was used solar desalination to solve the problem of shortage of fresh water. Solar energy can be directly used for a heating process to desalination work.

Solar desalination system widely investigated by many researchers. Praveen Hunashikatti et al., [1] are working on development on desalination unit using solar still coupled with evacuated tubes for domestic use. Soteris A. Kalogirou [2] mainly studies seawater desalination using renewable energy sources. This paper also includes a review of various systems that use renewable energy sources for desalination. Ashok Kumar Rajput et al. [3] mainly discusses the monthly averages of a sunshine hour and monthly variation of entire solar radiation are estimated. This paper also discusses the potential of estimation and utilization the solar energy and to solve the energy deficit in Pune district throughout the year. Their study shows that thermal and economic analysis of desalination system, he had used low-temperature multi-effect desalination system, they concluded that through multi-effect distillation method achievement for maximum thermal performance [4]. Jiang, et al., [5] was studied the compound parabolic concentrator of the novel mid temperature to retain certain temperature of water for desalination. Their results show that an evacuated tube CPC solar array can achieve $50 \%$ efficiency at $200{ }^{\circ} \mathrm{C}$ under a one sun condition. Gude, Veera Gnaneswar [6] mainly studies low-temperature desalination using solar collector augmented by thermal energy storage. This paper aims to provide a comprehensive review of all the indirect solar desalination technologies along with plant-specific technical details also economic feasibility and cost [7]. Affecting parameters for each desalination technology are also reviewed. Abhijeet Auti [8-9] mainly works on domestic solar water desalination system using parabolic concentrator they found that condensate water efficiency for finned system and 6 hours in a day to get 20 liters of soft water using parabolic concentrator also works on optical efficiency by varying different parameters. This paper mainly discusses the design and manufacturing of absorber for solar desalination system [10]. It is observed that absorber is more efficient for entire experimentation. Kedar et al. [11] mainly studies theoretical approach for hybrid solar desalination system using evacuated tube collector and compound parabolic concentrator. Their work mainly focuses on a theoretical and experimental study of a double slope still with fins immersed in a basin [12]. Their results show increasing the mass of water in the basin makes the productivity to go down. Satyamurthy et al. [13] carry out detailed experimental study on a conventional single slope solar still with sand heat energy storage for improving the yield of fresh water, their results show that solar still with and without energy storage materials was found to be 5.1 and 1.9 $\mathrm{kg} / \mathrm{m}^{2}$ day respectively. The paper mainly includes thermal analysis, for double slope solar still, was carried out based on internal and external heat transfer and energy balance equations to predict its performance [14]. They have mainly evaluated regarding recorded temperatures, instantaneous and internal thermal efficiencies, and system productivity. This paper mainly focuses on an overview of present desalination status and fresh water demand, fuel requirements, solar energy 
availability, thermal desalination technologies and solar thermal technologies of Oman has been presented in the paper [15]. The paper of Kedar et al. mainly focus on thermal analysis of evacuated tube collector as well as design and analysis of compound parabolic concentrator [16-17].

It can be observed from the literature survey that most of the studies carried out by the earlier researcher for analytical, experimental and numerical investigations. The present work involves an experimental investigation of a solar desalination system with evacuated tube collector to an objective of getting a maximum amount of soft water using the single effect boiling which will be useful for drinking purpose. Thus it should be noted that phenomenon of heat transfer from the evacuated outer surface of the tube to the inner surface of the tube and then water to enhance the formation of the steam goes for condensation to forms maximum soft water.

However inherent limitations of the experimental measurements and water flow through an evacuated tube with single effect boiling to form soft water is not found in the literature. The feature responsible for high heat rate and enhance the flow rate of water, temperature distribution for different environmental and climatic conditions of Pune city. Through this experimental investigation of evacuated tube collector, chemical analysis of the inlet and outlet water sample carried out as per (IS-10500:2012) drinking water standard. Chemical analysis shows distillate as well below the limit of drinking water specification.

\section{EXPERIMENTAL SET-UP}

The experimental set-up mainly consists of evacuated tubes, hard water tank, soft water collected jar, and surface condenser. The material used for evacuated tube was borosilicate glass tube along with black coating to internal tubes to increase the absorptive of solar radiation. Evacuated tubes are placed at the entire solar radiation angle longitude $74.15^{\circ}$ ( $74.9^{\prime}$ east), Latitude $18.6^{0}$ ( $18^{0} 36^{\prime}$ north). A frame is fixed to different evacuated tubes with rubber gaskets along with single manifold through which steam passes to the surface condenser. One water tank is connected to the evacuated tubes and another for the surface condenser. To collect the distillate water, jars are placed at the ends of these hosepipes for the collection of soft water. The angle of inclination to be mentioned of the evacuated tube collector is equal to the latitude of Pune location.

Table 1. Evacuated tube collector configuration

\begin{tabular}{|c|c|c|c|}
\hline $\begin{array}{c}\text { Sr. } \\
\text { No. }\end{array}$ & ETC Related Parameter & Symbol & Dimension \\
\hline 01 & ID of Tube & $\mathrm{d}$ & $47 \mathrm{~mm}$ \\
\hline 02 & OD of Tube & $\mathrm{D}$ & $65 \mathrm{~mm}$ \\
\hline 03 & $\begin{array}{c}\text { Internal surface between } \\
\text { tubes }\end{array}$ & $\mathrm{B}$ & $116 \mathrm{~mm}$ \\
\hline 04 & Length of the tube & $\mathrm{L}$ & $1500 \mathrm{~mm}$ \\
\hline 05 & Glass Thickness & $\mathrm{T}$ & $1.6 \mathrm{~mm}$ \\
\hline 06 & Absorber Area & $\mathrm{A}$ & $1.6 \mathrm{~m}^{2}$ \\
\hline 07 & Normal Projection Factor & $\mathrm{T}$ & 0.92 \\
\hline 08 & Normal Absorption Factor & $\mathrm{A}$ & 0.86 \\
\hline 09 & Heat loss coefficient & $\mathrm{U}_{\mathrm{L}}$ & $2 \mathrm{w} / \mathrm{m}^{2}{ }^{0} \mathrm{C}$ \\
\hline 10 & Heat loss factor & $\mathrm{FR}$ & 0.95 \\
\hline 11 & Refractive Index & $\mathrm{N}$ & 1.474 \\
\hline
\end{tabular}

The different instruments are used for measuring various parameters in the desalination system. Thermocouples are used to measure various temperatures, outer glass surface temperature, the water temperature in evacuated tubes and outlet distilled temperature. Along with that wind velocity of the glass surface to be measured by using an anemometer. The various experiments were conducted for different days in April and May 2017. The amount of distillate collected in measured with jars and data to be collected for wind velocity, various temperatures and intensity of solar radiation for the entire setup in the same campus where experiments were carried out.

Table 2. Instruments used for experimentation

\begin{tabular}{|c|c|c|c|c|}
\hline $\begin{array}{c}\text { Sr. } \\
\text { No. }\end{array}$ & Parameter & Instrument & Type/Model & Range \\
\hline 01 & Temperature & $\begin{array}{c}\text { Infrared } \\
\text { Thermometer }\end{array}$ & IRL-380 & $\begin{array}{c}-50 \text { to } \\
380^{\circ} \mathrm{C}\end{array}$ \\
\hline 02 & $\begin{array}{c}\text { Wind } \\
\text { Velocity }\end{array}$ & Anemometer & KM -910 & $\begin{array}{c}0.0 \text { to } \\
45 \mathrm{~m} / \mathrm{s}\end{array}$ \\
\hline 03 & $\begin{array}{c}\text { Intensity of } \\
\text { Solar } \\
\text { radiation }\end{array}$ & $\begin{array}{c}\text { Pyronometer } \\
\text { (Solar Power } \\
\text { Meter) }\end{array}$ & $\begin{array}{c}\text { KM-SPM- } \\
0-2000 \\
\mathrm{~W} / \mathrm{m}^{2}\end{array}$ \\
\hline 04 & $\begin{array}{c}\text { Flow rate of } \\
\text { water }\end{array}$ & $\begin{array}{c}\text { Water Flow } \\
\text { meter }\end{array}$ & STD & $\begin{array}{c}0.01- \\
100 \\
1 \mathrm{pm}\end{array}$ \\
\hline
\end{tabular}

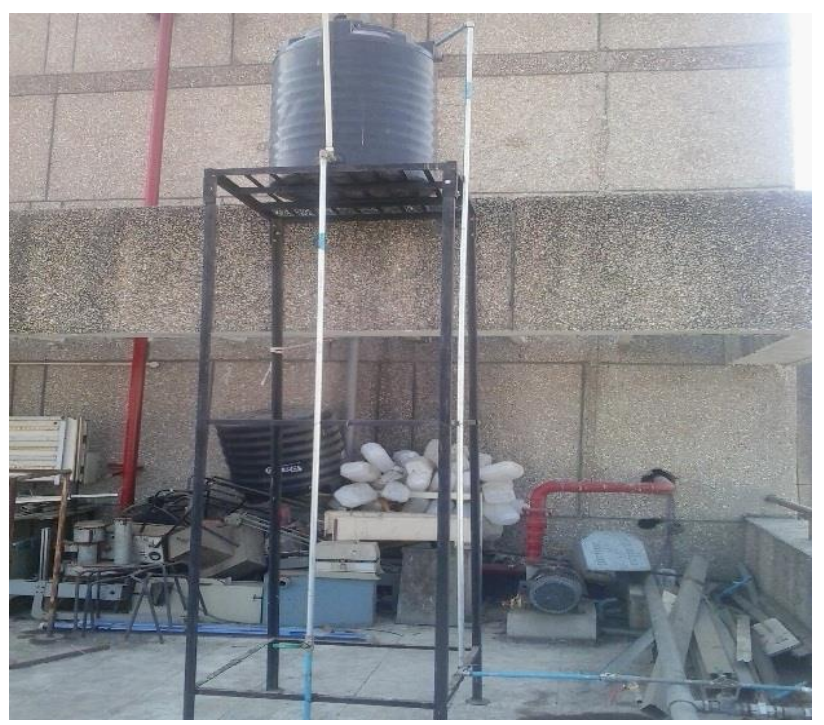

Figure 1. Hard water tank

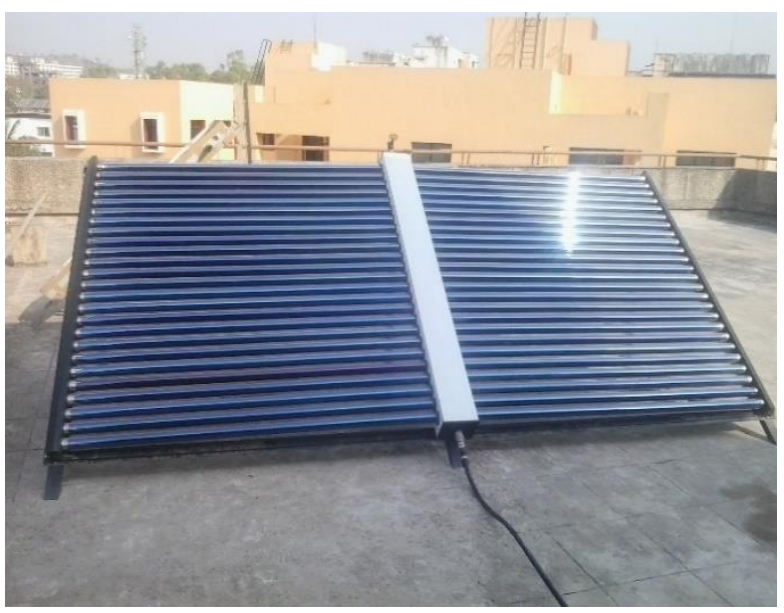

Figure 2. Evacuated tube collector 


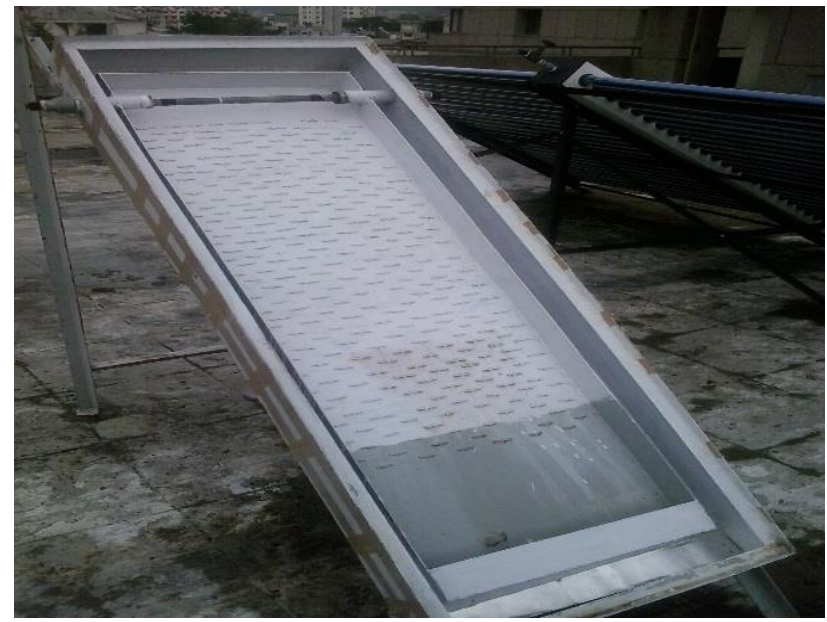

Figure 3. Surface condenser

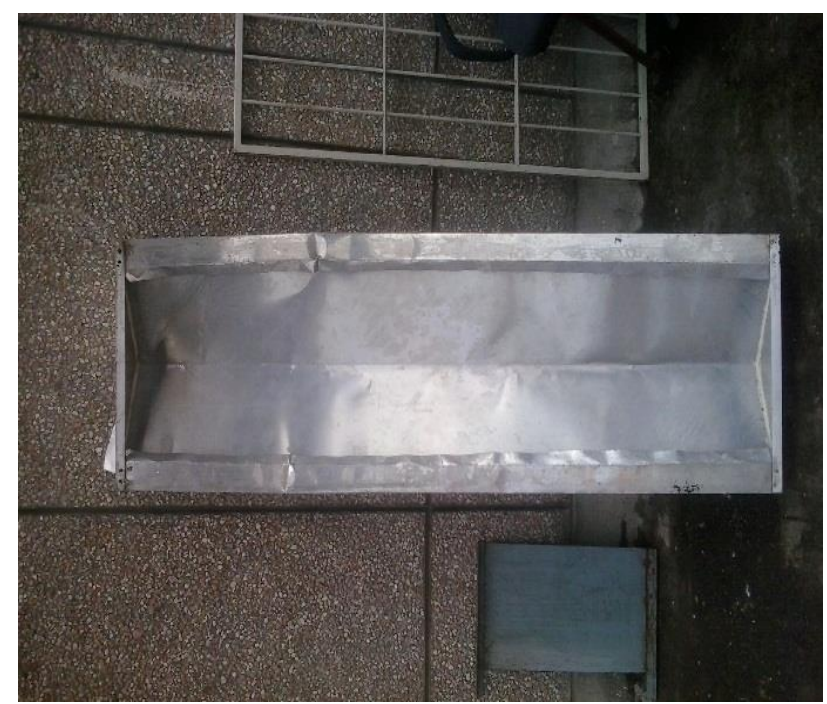

Figure 4. Upper side cover of surface condenser

The experiments were carried out in the premises of MKSSS's Cummins College of engineering for women, Karvenagar Pune which lies at $74.15^{\circ}$ ( $74^{\circ} 9^{\prime}$ east) longitude and $18.6^{\circ}\left(18^{\circ} 36^{\prime}\right.$ north) latitude depends on the variation of direct, diffuse and global solar radiation. The entire test was done during the period from April to May 2017 from 7:00 to 19:00 h. The setup mainly consists of evacuated tubes. The tubes are made from a type of glass called Borosilicate. Borosilicate glass has the characteristics of being very strong and excellent light transparency, black coating inside ETC tubes increase its absorptivity of solar radiation. Evacuated tubes are fixed to the basin using rubber gaskets. The water tank is connected to the inlet system of the evacuated tube manifold. The condenser is mounted near to the evacuated tube collector system for condensation of high-temperature steam and continuous flow of water into the system. To collect the distilled water, jars are placed at the end of hosepipe connected to the outlet of the system. The angle of inclination of the evacuated tube collector is equal to the latitude of Pune location.

\section{OPERATING PRINCIPLE AND PROCEDURE}

Operation of the entire system is similar to the natural thermosyphon solar water heating system. Solar radiations strike on glass cover, penetrate into inner glass tube and water. Water heated to a higher temperature and converted into steam. Due to a difference in the volatility on the internal surface of the surface condenser. Eventually leaving back the salt and chemical contaminants water drip down to the channel and in collected into Jar/bottle. The collected water is free from any chemical contaminants which are fit for drinking and industrial applications.

Experiments are carried out for different days as per environmental and climatic conditions of Pune city which is located in Weston reason of INDIA. The chemical analysis of both the initial hard water sample and a final water sample was compared with Indian Standard (ISO-10500-2012). The experiments are carried out from Morning 6:30 AM to evening 5:30 PM for various parameters such as temperature, wind velocity, water flow rates and intensity of solar radiation. The glass cover and condenser plate are cleaned daily to ensure that parameters not affected by dust.

\section{RESULTS AND DISCUSSIONS}

Experiments were carried out from March 2017 to May 2017 and the results of various parameters recorded for some days. The hourly various parameters like solar radiation, ambient temperature, the outer surface temperature of ETC glass tube, the inner surface temperature of ETC glass tube and outlet distilled water temperature. Experiments are carried out for different water flow rates i.e. $0.01 \mathrm{lps}, 0.02 \mathrm{lps}$, etc. for the typical days in the month of May 2017. It can be observed that the maximum solar radiation of $915 \mathrm{w} / \mathrm{m}^{2}$ is reached at 13.00 $\mathrm{h}$. The maximum ambient temperature of water observed $39^{\circ}$. Maximum inner surface glass temperature and formation of steam at temperature $112^{\circ}$. Finally, outlet distillate temperature $62^{\circ}$ observed at 16:00 h. On that day Evacuated tube collector system was given 25-27 liters of soft water per day. For the next day flow of water slightly increased $0.02 \mathrm{lps}$ and different temperature are recorded. The ambient temperature of water observed $37^{\circ}$ maximum inner surface temperature $115^{\circ}$ and formation of steam at temperature $110^{\circ}$ finally outlet distillate temperature $64^{\circ}$ observed at 16.00 . In addition to that intensity of solar radiation measured per $\mathrm{hr}$, it was observed that maximum solar radiation of $907 \mathrm{w} / \mathrm{m}^{2}$.

The hourly wind velocity over the glass surface was also noted for all typical days on which different experiments are performed. Wind velocity profile also recorded over the glass surface. As the glass cover heated for maximum temperature water vapor passing through a surface condenser. In surface condenser condensation process occurs. As the glass cover is exposed to the atmosphere some amount of heat is to be dissipated to the surrounding. The temperature of the glass cover is an important parameter for the condensation of vapor. It is found that for the mentioned condition of wind velocity has less impact on distillate water. Hence the effect of wind on soft water formation is very low. The wind velocity on the surface of the glass cover ranged from 5 to $20 \mathrm{~m} / \mathrm{sec}$.

Repeated experiments are performed on this evacuated tube collector system (March-17 to May-17) on the different flow rate of water. In addition to that wind velocity also little effect for the formation of soft water with considering different experiments of temperature profile maximum temperature of the evacuated tube as well as steam temperature from evacuated tube to be more suitable for water flow rate $0.01 \mathrm{lps}$ for the better result formation of soft water. In conclusion that 
entire experimental set-up system was giving 27-28 liters of soft water per day.

Month Vs Monthly Avg.Sunshine Hour 12

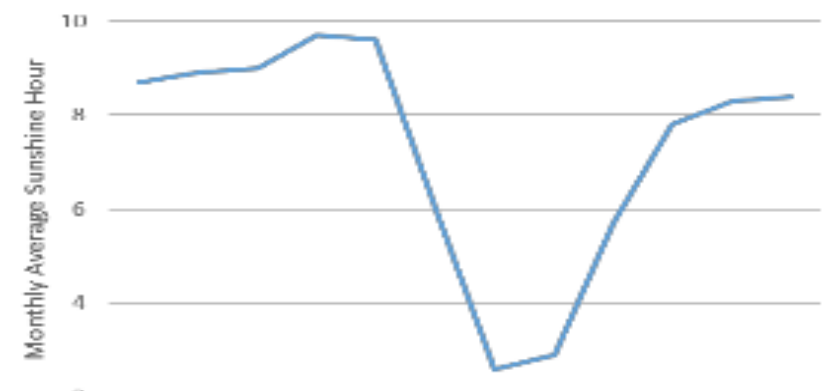

0

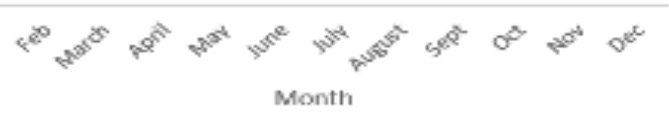

Figure 5. Monthly average sunshine hour of Pune City

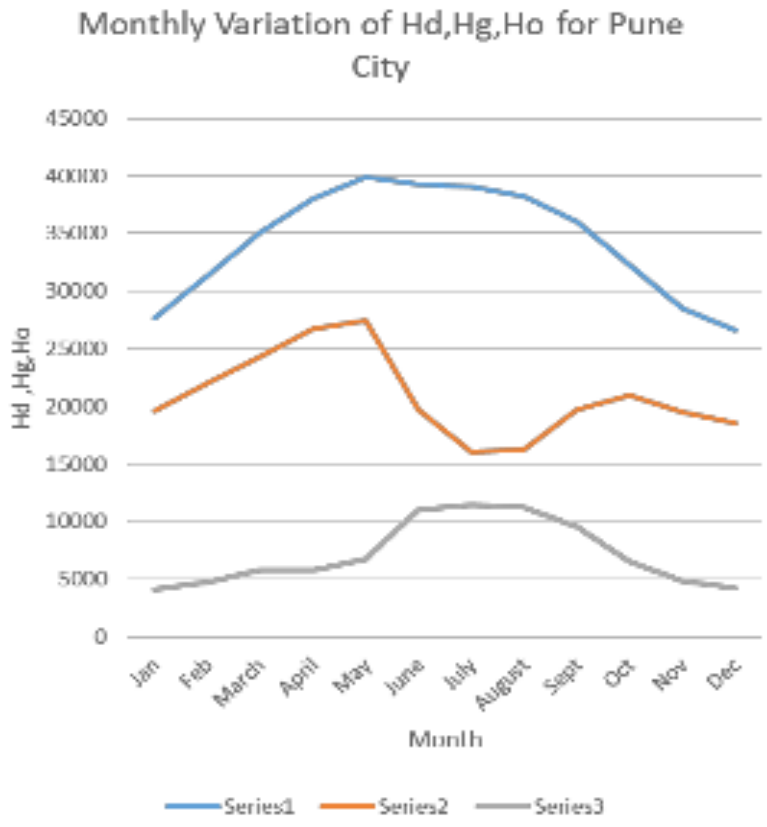

Figure 6. Monthly variation of direct, global and diffuse solar radiation of Pune City

As the figure 5 shows of Month Vs Monthly average sunshine hour mainly shows that in the month of January to May 17 large amount of intensity of solar radiation available as compared to June to September 17 after that October to December intensity of solar radiation gradually increased. In conclusion that 7-8 months average solar radiations were available in the Pune city. As figure 6 shows monthly variation of direct, global and diffuse solar radiation for the Pune city. The Utilization of the solar energy has the bright prospective future in Pune, Maharashtra, India

\section{Chemical Analysis of Water samples}

After Experimentation of evacuated tube collector system, there was a conversion of hard water and chemical analysis of hard water and soft water to be carried out. The results are shown in the table format. The values are obtained for chemical composition for both inlet and outlet water samples are compared with Indian standard drinking water specification (IS 10500:2012). These tabulated results prove that soft water from this desalination system which is fit drinking and industrial application. This system is successful for reducing total dissolved solids, hardness, and alkalinity present in the inlet water sample. The distilled water obtained from the system contain chemical parameters with drinking water standard specification.

The chemical analysis of both the samples shows that the system should be successful for reducing total hardness, chlorides, total dissolved solids, nitrates, magnesium. The distillate obtained from the system contains chemical parameters within the limits of Indian drinking water specification (IS 10500:2012). Table 3 shows that a detailed chemical analysis of water samples.

Table 3. Chemical analysis of water samples

\begin{tabular}{|c|c|c|c|c|}
\hline $\begin{array}{l}\text { Sr. } \\
\text { No. }\end{array}$ & Parameter & $\begin{array}{c}\text { Inlet } \\
\text { Sample }\end{array}$ & $\begin{array}{c}\text { Water } \\
\text { Acceptable } \\
\text { limit as per } \\
\text { IS } \\
\text { 10500:2012 }\end{array}$ & $\begin{array}{c}\text { Outlet } \\
\text { Sample }\end{array}$ \\
\hline 01 & $\mathrm{P}_{\mathrm{H}}$ & 7.35 & $6.5-8.5$ & 7.23 \\
\hline 02 & Turbidity (NTU) & Nil & 1(Max.) & Nil \\
\hline 03 & $\begin{array}{c}\text { Total Alkalinity } \\
\text { as } \\
\mathrm{CaCo}_{3} \text { (mg/Litre) }\end{array}$ & 425.00 & 200(Max.) & 30.00 \\
\hline 04 & $\begin{array}{c}\text { Total Hardness } \\
\mathrm{CaCo}_{3} \text { (mg/Litre) }\end{array}$ & 495.00 & 200(Max.) & 20.00 \\
\hline 05 & $\begin{array}{c}\text { Chlorides as CI } \\
\text { (mg/Litre) }\end{array}$ & 127.62 & 250(Max.) & 7.09 \\
\hline 06 & $\begin{array}{c}\text { Total dissolved } \\
\text { solids(mg/Litre) }\end{array}$ & 1070.00 & 500(Max) & 60.00 \\
\hline 07 & $\begin{array}{l}\text { Iron as Fe } \\
\text { (mg/Litre) }\end{array}$ & 0.28 & 0.3 (Max.) & Nil \\
\hline 08 & $\begin{array}{c}\text { Sulfates as } \mathrm{SO}_{4} \\
(\mathrm{mg} / \mathrm{Litre})\end{array}$ & 12.20 & 200(Max.) & Nil \\
\hline 09 & $\begin{array}{c}\text { Nitrates as } \\
\mathrm{NO}_{3} * \mathrm{mg} / \text { Litre) }\end{array}$ & 1.89 & 45(Max.) & Nil \\
\hline 10 & $\begin{array}{c}\text { Fluoride as F } \\
\text { (mg/Litre) }\end{array}$ & Nil & 1 (max.) & Nil \\
\hline 11 & $\begin{array}{c}\text { Calcium as } \mathrm{Ca} \\
\text { (mg/Litre) }\end{array}$ & 120.00 & 75(Max.) & 4.80 \\
\hline 12 & $\begin{array}{l}\text { Magnesium as } \\
\mathrm{Mg} \text { (mg/Litre) }\end{array}$ & 47.38 & 30(Max) & 1.944 \\
\hline 13 & $\begin{array}{c}\text { Coliform } \\
\text { MPN(No.Per } 100 \\
\text { ml) }\end{array}$ & Nilo & Nil & Nil \\
\hline 14 & $\begin{array}{l}\text { E.Coil(Per } 100 \\
\mathrm{ml})\end{array}$ & Absent & Absent & Absent \\
\hline 15 & Conclusion & $\begin{array}{l}\text { Unfit for } \\
\text { Drinking } \\
\end{array}$ & & $\begin{array}{c}\text { Fit for } \\
\text { Drinking }\end{array}$ \\
\hline
\end{tabular}




\section{CONCLUSION AND FUTURE WORK}

In the present work, a solar desalination system developed with the help of evacuated tube collector system. This system is fabricated and tested for environmental and climatic conditions of Pune city. Based on various experiments conducted and the above discussion the following conclusion is drawn: -

1) An experimental investigation using evacuated tube collector system to get 25-27 liters of soft water per day which is useful for drinking and industrial application. Usually, in case of rural areas water for bathing is heated by burning wood, leaves or cow dung, which deals with emission of carbon dioxide, carbon monoxide to atmosphere and water is observed at high temperature in range $75^{\circ}-90^{\circ} \mathrm{C}$. This eco friendly system does not depends upon any conventional sources of energy for its operation. Future work will be specifically targeted to increase distillate water using hybrid energy system.

2) The developed system is successful in reducing the excess hardness, total dissolved solids, chemical contaminants of inlet water sample. The chemical composition of distillate obtained satisfied as per drinking water standard (IS 10500:2012).

\section{ACKNOWLEDGMENT}

The project (15ENG000570) supported by Board of college and University Development (BCUD) Savitribai Phule Pune University (SPPU), Pune and Cummins College of Engineering for Women are gratefully acknowledged.

\section{REFERENCES}

[1] Hunashikatti, P.T., Suresh, K.R., Prathima, B. (2014). Development of desalination unit using solar still coupled with evacuated tubes for domestic use in rural areas. Current Science, 107(10): 1683-1693. https://www.jstor.org/stable/24107942

[2] Kalogirou, S.A. (2005). Seawater desalination using renewable energy sources. Elsevier Process in Energy and Combustion Science, 31(3): 242-281 https://doi.org/10.1016/j.pecs.2005.03.001

[3] Rajput, A.K. (2012). Utility-based estimated solar radiation at destination Pune, Maharashtra, India. International Journal of Pure and Applied Sciences and Technology, 13(1): 19-26.

[4] Liu, X.H. (2013). Thermal and economic analyses of solar desalination system with evacuated tube collector. Solar Energy, 93: 144-150. https://doi.org/10.1016/j.solener.2013.03.009

[5] Jiang, J.L., Widyolar, B., Winston, R. (2015). Characteristics of novel mid-temperature CPC solar thermal collectors. Energy Procedia, 70: 65-70. https://doi.org/10.1016/j.egypro.2015.02.098

[6] Gude, V.G., Nirmalakhandan, N., Deng, S., Maganti, A. (2012). Low temperature desalination using solar collectors augmented by thermal energy storage. Applied Energy, 91(1): 466-474. https://doi.org/10.1016/j.apenergy.2011.10.018
[7] Ali, M.T., Fath, H.E.S., Armstrong, P.R. (2011). Comprehensive Techno-economical Review of indirect solar desalination. Renewable and Sustainable Energy Reviews, 15: 4187-4199. https://doi.org/10.1016/j.rser.2011.05.012

[8] Auti, A.B. (2012). Domestic solar water desalination system. Energy Procedia, 14: 1774-1779. https://doi.org/10.1016/j.egypro.2011.12.1166

[9] Auti, A., Singh, T., Pangavhane, D., Chavan, A. (2013). Solar water desalination system with condenser without using electricity for rural areas. American Journal of Applied Sciences, 10(9): 1109-1114. https://doi.org/10.3844/ajassp.2013.1109.1114

[10] Sapre, M.S., Auti, A. (2014). Design and manufacturing of absorber for solar desalination system. Applied Mechanics and Materials, 446-447: 716-720. https://doi.org/10.4028/www.scientific.net/AMM.446447.716

[11] Kedar, S.A., Bewoor, A.K., Madhusudan, S. (2016). Solar desalination system using evacuated tube collector \& compound parabolic concentrator-theoretical approach. National Conference on Advancement in Electrical Engineering and Energy Sciences (AEEES2016) NIT Hamidpur.AEEES_757, pp. 60-62.

[12] Moungar, H., Ahmed, A., Youcef, S., Aabdelkrim, H. (2017). Immersed fins influence on the double slope solar still production in south Algeria climatic condition. International Journal of Heat and Technology, 35(4): 1065-1071. https://doi.org/10.18280/ijht.350444

[13] Satyamurthy, R., Nagarajan, P.K., Edwin, M., Madhu, B., El-Agouz, S.A., Ahsan, A., Mangeshbabu, D. (2016). Experimental investigations on conventional solar still with sand heat energy storage. International Journal of Heat and Technology, 35(4): 597-603. https://doi.org/10.18280/ijht.340407

[14] Morod, M.M., El-Maghawry, H.A.M., Wasfy, K.I. (2005). Improving the double slope solar still performance by using flat-plate solar collector and cooling glass cover. Desalination, 373: 1-9. http://dx.doi.org/10.1016/j.desal.2015.06.017

[15] Bhambare Parimal, S., Mujumder, M.C., Sudhir, C.V. (2018). Solar thermal desalination: A sustainable alternative for sultanate of Oman. International Journal of Renewable Energy Research, 8(2).

[16] Kedar, S.A., Kumaravel, A.R., Bewoor, A.K. (2018). Thermal analysis of solar desalination system using evacuated tube collector. AIP Conference Proceedings, 2039(1): 020061. http://dx.doi.org/10.1063/1.5079020

[17] Kedar, S.A., Kumaravel, A.R., Bewoor, A.K. (2018). Design and analysis of solar desalination system using compound parabolic concentrator. IOP Conf. Series: Materials Science and Engineering, 455: 012063. http://dx.doi.org/10.1088/1757-899X/455/1/012063

\section{NOMENCLATURE}

d Inner diameter of Tube

D Outer diameter of Tube

B Internal surface between tubes

L Length of the Tube

t Glass thickness

A Absorber area

$\tau \quad$ Normal Projection factor 
a Normal absorption factor

$\mathrm{U}_{\mathrm{L}} \quad$ Heat loss coefficient

$\mathrm{F}_{\mathrm{R}} \quad$ Heat loss factor

$\mathrm{N} \quad$ Refractive Index

$\mathrm{T}$ Temperature

V Wind velocity

I Intensity of solar radiation

$\mathrm{H}_{\mathrm{d}} \quad$ Global solar radiation
$\mathrm{H}_{\mathrm{g}} \quad$ Average daily global solar radiation

$\mathrm{H}_{\mathrm{o}} \quad$ Direct solar radiation

$\mathrm{Kt} \quad$ Clearness Index

$\mathrm{Ca} \quad$ Calcium

F Fluorine

$\mathrm{Mg}$ Magnesium

TDS Total Dissolved Solids 